\title{
Innovation and Enterpreneurship Education and Specialized Education
}

\author{
Mingzhu Qian \\ Huanghe Science and Technology College \\ Zhengzhou, Henan, China
}

\begin{abstract}
The Central Party and the State Council pay high attention to the education of innovation and entrepreneurship in colleges and universities. The 18th National Congress of the Communist Party of China clearly mentioned that it was necessary to increase support for the cultivation of innovation talents. Party secretary Xi Jinping repeatedly made important instructions to speed up the reform of education system, pay attention to cultivate students' innovation spirit, and creating innovation and entrepreneurship talents team of the large-scale, innovation spirit and the courage to take risks. Colleges and universities become the main force in innovation and entrepreneurship educational work. In order to adapt to new situation and new requirements, solidly advance innovation and entrepreneurship education reform, to provide students with innovation entrepreneurship courses learning platform. Many colleges and universities opened entrepreneurship education courses for students. But course content does not match, many students learning the employment of entrepreneurial courses after, no clear target and do not know how to start. For this problem, it is so important to research the organic integration of innovation and entrepreneurship education and specialize education in colleges and universities.
\end{abstract}

Keywords-university and college; innovation and entrepreneurship education; specialized education; organic integration

\section{INTRODUCTION}

From the end of the 19th century, specialized education in the university has occupied an unshakable position. To the early 20th century, specialized education has become the mainstream-oriented in the university education. Entrepreneurship education should be attached to the specialized education, it is because successful entrepreneurship education must have specialized education as a basis. At the same time, specialized education reform also needs the integration of entrepreneurship education to meet new requirements. University for the students' training goal need combine specialized education and entrepreneurship education to form, thus, to cultivate highquality talents with innovation spirit and practical ability. With the development of society, the specialized education of higher education in our country is also changing. The goal of personnel training changes with the change of people 's work position and content, which adapting to the diversity and innovation of social development. Through innovation and entrepreneurship education enable students to master the learning methods, principles of work, common cooperation, learning to survive, to achieve the ability of life-long development, and reflecting the specialized education required professional and practical ability. The fusion of innovation and entrepreneurship education in the specialized education and teaching, to achieve sustainable development strategy. Specialized education is the basis of entrepreneurship education, which to provide academic practice and basic knowledge, training students have a strategic vision, marketing ability, decision-making ability, good communication skills, coordination skills and strong competitiveness.

\section{THE IMPORTANCE OF ORGANIC INTEGRATION OF UNIVERSITY AND COLLEGE INNOVATION AND ENTREPRENEURSHIP EDUCATION \& SPECIALIZED EDUCATION}

Education Secretary of department leading Party Group, minister Yuan Guiren propose, "we should make efforts to realize the transformation from innovation to entrepreneurship education and specialized education from organic to organic integration in the video conference of innovation and entrepreneurship education reform in colleges and universities." Yuan Guiren pointed that firmly establish the concept of advanced innovation and entrepreneurship education, from focus on knowledge transfer to focus on innovation, entrepreneurship and innovation and entrepreneurship training. And effectively enhance the students' innovative spirit, entreprise consiousness and innovation and entrepreneurship ability. There are two forms of higher education in China: one is specialized education, the other is entrepreneurship education. Although entrepreneurship education and specialized education have differents educational goals and contents, they are interdependent and indispensable, both are training goals of university and college. Entrepreneurship education is to train students' entreprise consiousness, entrepreneurial thinking, entrepreneurial skills and other entrepreneurial qualities, and ultimately to be educated with a certain entrepreneurial ability of education. Through entrepreneurship education enable students to master the basic theory and methods of entrepreneurship, familiar with the country's preferential policies and measures to foster innovation awareness, tap the potential of entrepreneurship, so that students have the ability to start a business, to meet 
the national standards for compound talents. Specialised education focus on the accumulation of academic knowledge and training of professional skills, which is survival of students into the career path is the future. In the specialised education, it should be integrated innovation and entrepreneurship education concept and implementation method. Making innovation and entrepreneurship education deeply into specialised education, and reflects innovative concept.

\section{The Status QUO AND PROBLEMS OF INNOVATION AND ENTREPRENEURSHIP EDUCATION IN CHINESE UNIVERSITIES AND COLLEGES}

Many documents issued by the government mention that universities should attach importance to innovation and entrepreneurship education. The party, government and education authorities attach great importance as well. China's recent gratifying achievements in innovation and entrepreneurial education, but there are also unavoidable places are not satisfactory. Looking at the current situation of innovation and entrepreneurship education in China's colleges and universities, the following problems are found.

\section{A. Innovation and Entrepreneurship Education Concept Is Difficult to In-depth}

Although the state of innovation and entrepreneurship education to a high position, but it is difficult to implement down, as an educational entity, colleges and universities failed to understand the strategic significance of innovation and entrepreneurship education, but parrot, cannot look to the future.

\section{B. Innovative Entrepreneurial Professional Teaching Staff Is Weakness}

At present, most colleges and universities are set up innovation and entrepreneurship education courses, this kind of course teachers, a part is specialized courses teachers, part for other is part-time teachers, they are the lack of professional full-time teachers team. These teachers are not deep in the study of innovation and entrepreneurship education, the lack of professional knowledge system and sense of innovation, in the classroom is difficult to targeted students to be guided.

\section{The Gap between Innovation and Entrepreneurship Education \& Specialized Education}

Most of the innovation and entrepreneurship education in colleges and universities cannot be combined with specialized education. Just has innovation and entrepreneurship education courses, and this course is general compulsory course, which divorced from the students' professional, making innovation and entrepreneurship education without professional support and lose their original meaning.

\section{Innovation and Entrepreneurship Education Failed Integrate into the Professional Training Program}

At present, many colleges and universities of innovation and entrepreneurship education only stay in the promotion of entrepreneurial policy, entrepreneurial information and entrepreneurial knowledge to impart, however, these are not only linked to specialized education, but also not added to the professional training program.

\section{E. Innovation and Entrepreneurship Education Quality Evaluation Mechanism Is Imperfect}

The national higher education authorities have not set up the content of innovation and entrepreneurship education in the evaluation of educational quality of higher education institutions, nor have they introduced social enterprises or third-party assessment institutions to evaluate the quality of innovation and entrepreneurship education and failed to form good innovation and entrepreneurship atmosphere, the universities should also pay more attention.

\section{RESEARCH ON THE PATH OF INNOVATION INTEGRATION OF ENTREPRENEURSHIP EDUCATION AND SPECIALIZED EDUCATION IN COLLEGES AND UNIVERSITIES}

\section{A. Strengthening the Integration of Innovation, Enterprise Education and Specialized Education}

Premier Li Keqiang in the "Government Work Report", 38 times referred to the "Innovation", 13 times referred to "Entrepreneurship", in particular, twice specifically referred to "Public entrepreneurship, Peoples Innovation", we can see that innovation and entrepreneurship is currently all industry focus. Colleges and universities is the main force to cultivate innovation talents, which should establish the awareness of innovation and entrepreneurship, and pay attention to cultivate students' innovation and entrepreneurship ability. Firstly, we must understand the importance of innovation and entrepreneurship education, change the original single specialized education model. Innovation and entrepreneurship education is to cultivate students with enterprise consciousness and entrepreneurial spirit, so that students master the concept, elements and characteristics of entrepreneurship with the basic quality of innovation talents. Training students' critical thinking, insight, decision-making power, organizational coordination, leadership and other innovation entrepreneurial qualities, make students have the necessary entrepreneurial ability. The purpose of speicalized education is through professional courses to learn, master the basic knowledge and skills of the profession, so that students can successfully go to work and complete social production activities. Secondly, innovation and entrepreneurship education is inseparable from the basic support of specialized education, the two interrelated mutual penetration. Innovation and entrepreneurship education cannot separate concepts from the professional content, which out of the higher education to cultivate talents training objectives of high-quality and high knowledge skill. The implementation of specialized education should be combined with the content of innovation and entrepreneurship education, students not only master the basic knowledge and 
professional skills, but also establish a sense of innovation and entrepreneurship, entrepreneurial spirit, understand the industry foreword information to meet the requirements of the new era of social development.

\section{B. Strengthening the Integration of Specialized Education and Entrepreneurship Education Curriculum}

Curriculum is the core of the teaching work, and the main path to implement innovation and entrepreneurship education objectives. Through the curriculum structure system and the practical work of teaching content, show that concept of combine with innovation and entrepreneurship education and the specialized education. To strengthen the integration of specialized education and entrepreneurship education curriculum system, can effectively obtain the convergence of knowledge, establishment of a reasonable curriculum content, institution and closely related to entrepreneurship courses for the students to provide professional entrepreneurship theory, knowledge, skills and methods. On the one hand, we must infiltrate the innovation and entrepreneurship education in specialized education, strengthen the integration of innovation and entrepreneurship courses and specialized courses, according to the necessary knowledge structure of specialized talents to build a comprehensive curriculum system. In this way, both the effective use of classroom resources, expanding the application of specialized education, and saves the education time, optimize the teaching content. On the other hand, professional courses teacher should change the teaching methods, the spirit of the innovation and entrepreneurship training throughout the classroom teaching the whole process, through a variety of teaching methods to develop students ability of recognition of problems and problem-solving. In the course content arrangement, to increase the comprehensive curriculum, interdisciplinary and edge disciplines courses, broaden the knowledge of students, play students non-intellectual factors. Setting up innovation and entrepreneurship educational courses and various forms of seminars, which cultivate to students management, management capacity. For original senior employment guidance course translated into curriculum group of innovation and entrepreneurship education for four-year university. Teaching entrepreneurial knowledge and entrepreneurial skills to further stimulate students' interest in learning and cultivate their innovation spirit and entrepreneurial consciousness.

\section{Construction Practice Platform, to Realize the Integration of Entrepreneurship Education and Specialized Education}

Due to the professional comprehensive quality more and more attention by the employing units, we should pay attention to college students' innovation and entrepreneurship practice ability. To achieve this goal, we should organically integrate the practice teaching of specialized education with the actual training of innovation and entrepreneurship education, make them mutual penetration and promotion.
1) Offering entrepreneurial practice course: Colleges and universities can choose the appropriate enterprises according to the nature and characteristics of different majors and cooperate with them to establish the practice base of college students' entrepreneurship and encourage students with entrepreneurial intention to learn of more practical entrepreneurial knowledge and experience. Through hold the venture forums, entrepreneurial competition, entrepreneurial website construction and other forms of extra-curricular entrepreneurship activities to promote student entrepreneurship groups communication and exchange.

2) Established entrepreneurial practice base: Colleges and universities should provide students with entrepreneurial opportunities and platforms, and establish innovation park to encourage students to declare their own innovation projects, entrepreneurial activities in schools, and accumulate valuable experience for the future into the community and lay a good foundation. The author work at the Huanghe Science and Technology College, there established student innovation park, and the student innovation hall covers an area of nearly a thousand square meters, to meet the professional employment of entrepreneurship base, regularly carry out the concept of employment and entrepreneurship seminars, entrepreneurial achievements report, entrepreneurial and practical Skills training, entrepreneurship education and training, annual entrepreneurship forum held for students to open up the project incubator self-help channels.

\section{Strengthening the Construction of Teaching Staff and \\ Promoting the Integration of Entrepreneurship \\ Education and Specialized Education}

The school should pay full attention to the building of the innovation and entrepreneurship educational teacher team, not to separate from the specialized education and the innovation and entrepreneurship education. The specialized education is focused on master the system theory knowledge of students, entrepreneurship education is focused on students problems solving and innovation practical ability. In the composition of teachers, specialized education teachers have a solid background in professional knowledge, can assume the task of theoretical teaching, but its entrepreneurial education knowledge and skills are naturally inadequate. Although entrepreneurial education of teacher has a wealth of entrepreneurial education knowledge and skills, the lack of relatively specialized theoretical knowledge. At present, most colleges and universities do not have a special teacher team of the innovation and entrepreneurship education. The universities and colleges can choose from the specialized full-time teachers with strong entrepreneurial consciousness, according to the actual needs of entrepreneurship education to targeted training for them, and provide more opportunities to teachers participate in domestic and international innovation and entrepreneurship field of academic exchanges and research conditions. At the same time, sending some core teachers to the school or college, which has excellent innovation and 
entrepreneurship education model in China. Innovation and entrepreneurship education needs the teacher have the strong practice ability, but this is weakness in Chinese university. In order to make up for this weakness, the universities can hire some successful entrepreneurs and technical innovation experts, as the school part-time teachers or visiting professors to teach students. Demonstration successful teaching cases and established experts database and entrepreneurship cases database. In addition, teachers can also be arranged to temporary learning in the appropriate business and department, to improve their innovation and entrepreneurship ability.

\section{CONCLUSION}

Innovation and entrepreneurship education and specialized education is an integral part of the entire higher education activities, the purpose is to cultivate the highquality talents of innovation spirit and entrepreneurial ability. There is no absolute distinction between innovation and entrepreneurship education and specialized education, specialized education is the foundation, innovation and entrepreneurship education is the practice. Although they cannot replace each other, can be integrated with each other and promoted each other. We should organically integrate the innovation and entrepreneurship education with specialized education, fully penetrated innovation and entrepreneurship education in specialized education, strengthen students professional knowledge base, improve the overall quality of students and innovation and entrepreneurship ability. The integration of innovation and entrepreneurship education and specialized education is the requirement of the progress and development of higher education. It is also an important measure to promote the training of high - level talents and the inevitable choice of higher education reform.

\section{REFERENCES}

[1] Zheng xiaohong, Xie xiayu, andLiu hairong, "Innovating the Mode of Enterprise Education in Universities and Cultivating Students' Potential of Starting Their Own Business" China University Students Career Guide. 2011.13.

[2] Mao guotao, Analysis on the Construction of "1 $+\mathrm{N}$ " Curriculum System in Innovation and Entrepreneurship Education, Journal of Nanchang College of Education, 2011.05.

[3] Shi guoliang, “University Students' Innovation and Entrepreneurship Education" Journal of Ideological \& Theoretical Education, 2010.10.

[4] Wang li, "A Study on the Way of Symbiotic Integration of Entrepreneurship Education and Professional Education", Journal of Wuxi Institute of Commerce, 2010. 5.

[5] Peng wenbo,Yin xinming,Li guanfeng, "Exploration and Practice of Curriculum System Construction of Innovative and Enterprising Education" Innovation and Entrepreneurship Education, 2010.04. 